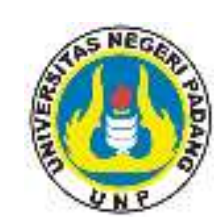

\title{
ANALISIS PENGGUNAAN GAYA BAHASA PADA LIRIK LAGU DALAM ALBUM HATSUKOI KARYA HIKARU UTADA
}

\section{Dharmala Febriyanti ${ }^{1}$, Nova Yulia ${ }^{2}$}

${ }^{1}$ (Mahasiswa Pendidikan Bahasa Jepang, Bahasa dan Sastra Inggris, Fakultas Bahasa dan Seni, Universitas Negeri Padang), Jl. Prof. Dr. Hamka Air Tawar, Padang, 25131

${ }^{2}$ (Dosen Pendidikan Bahasa Jepang, Bahasa dan Sastra Inggris, Fakultas Bahasa dan Seni, Universitas Negeri Padang), Jl. Prof. Dr. Hamka Air Tawar, Padang, 25131

Email Penulis : malayanti29@gmail.com

\begin{tabular}{lr}
\hline Sejarah Artikel \\
\hline Submit $: 2021-01-27$ \\
Diterima $: 201-01-28$ \\
Diterbitkan : 2021-06-09
\end{tabular}

\section{Kata Kunci:}

Gaya bahasa, lirik lagu,

Hikaru Utada

\begin{abstract}
The aim of this study was to describe the use of language style in song lyrics of Hatsukoi Album by Hikaru Utada. This study used a descriptive qualitative method. The data of this research were word, phrase or sentence which contains language style in song lyrics of Hatsukoi Album by Hikaru Utada. Meanwhile the data source in this research were 12 (twelve) song titles of Hatsukoi Album by Hikaru Utada. From the study found that they were 24 data used metaphor language style, with details: 14 ontological metaphor, 6 conceptual metaphor, 2 orientational metaphor, and 2 conduit metaphor. Then 13 data used metonymy language style with details: 8 metonymy data were zentai-bubun type, 4 metonymy data were gen-inkekka type, and 1 metonymy data was youki-nakami type. And last there were 10 data used sinekdoke language style.
\end{abstract}

\section{PENDAHULUAN}

Bahasa merupakan media atau sarana untuk menyampaikan sesuatu ide, pikiran, hasrat, dan keinginan kepada orang lain (Sutedi, 2004:2). Melalui bahasa manusia dapat menyampaikan keinginannya secara konkrit sehingga dapat dimengerti oleh pihak lain yang diajak berkomunikasi (Yulia, 2010:37). Bahasa digunakan dalam berbagai aspek, salah satunya adalah karya sastra.

Kehadiran bahasa dalam sebuah karya sastra memiliki peranan penting karena bahasa dijadikan sebagai medium utama dalam penyampaian hal tersebut. Wellek \& Werren (1995:14) mengatakan bahasa menjadi sarana pokok yang penting bagi pengarang dalam menuangkan imajinasinya. Pengarang menggunakan berbagai macam bentuk bahasa dalam karya sastranya untuk menciptakan efek estetik. Salah satu hal 
yang dilakukan pengarang untuk mencapai hal tersebut adalah dengan menggunakan gaya bahasa. Penggunaan gaya bahasa (style) adalah cara pemakaian bahasa dalam karangan, atau bagaimana seorang pengarang mengungkapkan sesuatu yang akan dikemukakan (Abrams dalam Al-Ma'ruf, 2009: 7). Gaya bahasa dapat diartikan sebagai cara khas yang dipergunakan oleh seseorang untuk mengutarakan atau mengungkapkan diri dengan gaya pribadi. Senada dengan itu, mengkaji gaya bahasa memungkinkan dapat menilai pribadi, karakter, dan kemampuan pengarang yang menggunakan bahasa tersebut. Kemudian gaya bahasa juga berhubungan erat dengan ideologi (pandangan hidup) dan latar sosiokultural pengarangnya.

Dalam buku mengenal linguistik kognitif, Sutedi (2016:45) membagi gaya bahasa menjadi 3 (tiga) kelompok yaitu metafora, metonimi, dan sinekdoke. Adapun contoh penggunaan gaya bahasa metafora menurut Sutedi (2016:58) yakni:

\section{君は僕の太陽だ。}

\section{Kimi wa boku no taiyou da.}

"kau adalah matahariku"

Dalam penelitian ini peneliti memilih lirik lagu pada album Hatsukoi karya Hikaru Utada karena lirik lagunya banyak menggunakan berbagai macam gaya bahasa yang mengandung makna tersirat, yang sulit untuk dipahami secara langsung arti dari kalimat lirik lagu tersebut. Penggunaan gaya bahasa dalam lirik lagu perlu diteliti agar tidak terjadi kesalahpahaman dalam penyampaian pesan dari lirik lagu tersebut. Hal ini dikarenakan gaya bahasa mengandung makna tersirat yang penting untuk dicari tahu arti dari kalimat tersebut. Oleh sebab itu, peneliti melakukan peneltian dengan judul "Analisis Penggunaan Gaya Bahasa Pada Lirik Lagu Dalam Album Hatsukoi Karya Hikaru Utada".

Adapun tujuan penelitian ini adalah untuk mendeskripsikan jenis gaya bahasa yang terkandung dalam lirik lagu yang dinyanyikan oleh Hikaru Utada pada album Hatsukoi.

Diharapkan penelitian ini dapat memberikan sumbangsih dalam menambah wawasan ilmu pengetahuan, membantu dalam meningkatkan pemahaman dibidang linguistik khusus dalam bidang penelitian gaya bahasa. Dan dapat dijadikan sebagai salah satu referensi yang dapat diaplikasikan dalam bidang kajian linguistik kognitif, serta dapat menjadi salah satu acuan bagi peneliti lain guna melakukan penelitian sejenis yang lebih luas dan mendalam.

\footnotetext{
${ }^{1}$ Mahasiswa Prodi Pendidikan Bahasa Jepang FBS UNP

${ }^{2}$ Dosen Prodi Pendidikan Bahasa Jepang FBS UNP
} 


\section{METODE PENELITIAN}

Jenis penelitian yang digunakan dalam penelitian ini adalah pendekatan kualitatif. Menurut Sugiyono (2013:12) penelitian kualitatif adalah metode penelitian yang berlandaskan pada filsafat postpositivisme, digunakan untuk meneliti pada kondisi obyek yang alamiah, dimana peneliti adalah sebagai instrumen kunci atau human instrument, teknik pengumpulan dilakukan secara gabungan, analisis data bersifat induktif/kualitatif, dan hasil penelitian kualitatif lebih menekankan makna dari pada generalisasi. Penelitian ini dikatakan kualitatif karena menggunakan data deskriptif berupa tuturan dan bukan berupa angka. Metode penelitian yang digunakan dalam penelitian ini adalah metode deskriptif. Menurut Sutedi (2009:58) penelitian deskriptif adalah penelitian yang dilakukan untuk menggambarkan, menjabarkan suatu fenomena yang terjadi saat ini dengan menggunakan prosedur ilmiah untuk menjawab masalah secara aktual. Penelitian ini bertujuan untuk mendeskripsikan penggunaan gaya bahasa pada lirik lagu dalam album Hatsukoi karya Hikaru Utada. Data dari penelitian ini adalah kata, frasa, atau kalimat yang mengandung 比喻 (hiyu) atau gaya bahasa, yang dianalisis dengan menggunakan teori Sutedi. Adapun sumber data dalam penelitian ini adalah 12 (dua belas) judul lagu yang terdapat pada album Hatsukoi karya Hikau Utada yaitu Play A Love Song, あなた (Anata)、初恋 (Hatsukoi), 誓い (Chikai), Forevermore, Too Proud Feauturing Jevon, Good Night, パクチーの唄 (Pakuchi No Uta)、残り香 (Nokoriga)、大空で抱きしめて (Oozora De Dakishimete)、夕此 (Yuunagi)、疦妬されるべき人生 (Shittosarerubeki Jinsei). Instrumen penelitian dalam penelitian ini adalah peneliti sendiri (human instrument). Menurut Sugiyono (2013:148) instrumen penelitian merupakan suatu alat yang digunakan untuk mengukur fenomena alam maupun sosial yang diamati. Teknik pengumpulan data yang dilakukan dalam penelitian ini adalah teknik analisis dokumen, dengan menggunakan alat bantu tabel inventaris data. Uji keabsahan data dalam penelitian ini dilakukan dengan cara meningkatkan ketekunan. Teknik analisis data dalam penelitian ini menggunakan alat bantu tabel klasifikasi data.

\section{HASIL DAN PEMBAHASAN}

\section{Hasil}

Dari data penggunaan gaya bahasa yang terdapat pada 12 judul lagu dalam album Hatsukoi karya Hikaru Utada, peneliti menemukan sebanyak 24 kalimat yang menggunakan gaya bahasa metafora dengan rincian 6 kalimat metafora konseptual, 2 kalimat metafora orientasional, 14 kalimat metafora ontologikal, dan 2 kalimat metafora saluran. Sebanyak 13 kalimat yang menggunakan gaya bahasa metonimi dengan rincian 1 kalimat metonimi yang memiliki hubungan tempat sesuatu dan isinya (youki-nakami), 8 kalimat metonimi yang memiliki hubungan bagian dan keseluruhan (zentai-bubun), dan 4 kalimat metonimi yang memiliki hubungan sebab dan akibat (gen-in---kekka). 
Kemudian, sebanyak 10 kalimat yang menggunakan gaya bahasa sinekdoke. Untuk lebih jelasnya, data penelitian ini akan dideskripsikan dengan tabel di bawah ini.

Tabel 3 Deskripsi Penggunaan Gaya Bahasa pada Lirik Lagu dalam Album Hatsukoi Karya Hikaru Utada

\begin{tabular}{|c|c|c|c|}
\hline \multirow{2}{*}{$\begin{array}{l}\text { No } \\
1\end{array}$} & \multicolumn{2}{|c|}{ Gaya Bahasa } & \multirow{2}{*}{$\begin{array}{c}\text { Jumlah Kalimat } \\
10\end{array}$} \\
\hline & \multirow[t]{4}{*}{ Metafora } & Konseptual & \\
\hline & & Orientasional & 2 \\
\hline & & Ontologikal & 14 \\
\hline & & Saluran & 2 \\
\hline & Jumlah & $1 \mathrm{H} \cdot \mathrm{C}$ & 28 \\
\hline \multirow[t]{4}{*}{2} & & $\begin{array}{l}\text { Tempat sesua } \\
\text { isinya (youki- }\end{array}$ & 1 \\
\hline & & $\begin{array}{l}\text { Bagian dan } \\
\text { keseluruhan ( } \\
\text { bubun) }\end{array}$ & 7 \\
\hline & & $\begin{array}{l}\text { Sebab dan ak } \\
\text { in---kekka) }\end{array}$ & 4 \\
\hline & Jumlah & & 12 \\
\hline 3 & Sinekdoke & + & 7 \\
\hline \multicolumn{2}{|c|}{ Jumlah Keseluruhan } & 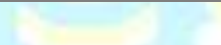 & 47 \\
\hline
\end{tabular}

Dari deskripsi data di atas, berikut penjelasan mengenai penggunaan gaya bahasa yang terdapat dalam album Hatsukoi karya Hikaru Utada:

\section{Metafora}

Metafora adalah gaya bahasa yang digunakan untuk menyatakan suatu hal (misalnya A) dengan menggunakan hal yang lain (misalnya B) atas dasar kesamaan atau kemiripan (ruijisei). Adapun pembagian metafora menurut Lakoff \& Johnson (dalam Sutedi, 2016:49) yaitu metafora konseptual (conceptual metaphor), metafora orientasional (orientational metaphor), metafora ontologikal (ontological metaphor), dan metafora saluran (conduit metaphor). Berdasarkan hasil penelitian, peneliti menemukan sebanyak 28 kalimat yang menggunakan gaya bahasa metafora, dengan rincian: 10 kalimat metafora konseptual, 2 kalimat metafora orientasional, 14 kalimat metafora ontologikal, dan 2 kalimat metafora saluran.

a. Metafora Konseptual

Dalam 12 (dua belas) judul lagu yang terdapat pada album Hatsukoi karya Hikaru Utada, peneliti menemukan sebanyak 10 kalimat yang mengandung gaya bahasa metafora konseptual, yaitu diantaranya data 1, 4, 5, 8, 13, 21, 23, 33, 36, dan 38. Berikut contoh data yang peneliti temukan dalam lirik lagu pada album Hatsukoi karya Hikaru Utada. 


\section{Data [1] 不安と戦う}

\section{Fuan to tatakau}

Berjuang dengan kecemasan

(Play a Love Song, bait ke-1, baris ke-4)

Pada data [1], ditemukan gaya bahasa metafora konseptual. Kata 不安と戦う "fuan to tatakau" /berjuang dengan kecemasan. Kata cemas memiliki arti khawatir/ takut/ gelisah. Sementara kata berjuang memiliki arti berusaha dengan sekuat tenaga akan sesuatu. Kata berjuang dan kecemasan seringkali digandengkan dengan kehidupan. Oleh sebab itu, kalimat 'berjuang dengan kecemasan' dianggap sebagai ranah sasaran yang sifatya abstrak. Sementara yang menjadi ranah sumber dalam kalimat ini adalah seseorang yang tidak optimistis, tidak yakin dan tidak percaya dengan kehidupan yang sedang ia jalani, takut akan rintangan-rintangan yang akan ia hadapi di depan. Jadi, ranah sumber merupakan penjabaran atas ranah sasaran/target yang sifatnya abstrak.

b. Metafora Orientasional

Dalam 12 (dua belas) judul lagu yang terdapat pada album Hatsukoi karya Hikaru Utada, peneliti menemukan 2 kalimat yang mengandung gaya bahasa metafora orientasional, yaitu data 44 dan 45 . Berikut contoh data yang peneliti temukan dalam lirik lagu pada album Hatsukoi karya Hikaru Utada.
Data [44]＼cjkstart落とさぬように抱いた 小さくなったあなたの体
Otosanu you ni daita Chiisaku natta anata no karada Aku peluk tubuhmu Jadi aku tidak akan menjatuhkannya Itu menjadi sangat kecil

(夕址 'Yuunagi', bait ke-4, baris ke-1\&2)

Pada data [44] ditemukan gaya bahasa metafora orientasional. Kata 落とさぬ 'otosanu'/jatuh, menjelaskan penggunaan arah secara ruang yaitu kebawah. Kata 'menjatuhkannya' yang dimaksud adalah keadaan ketika ia akan memeluk erat tubuh kekasihnya, tidak akan melepaskan dan tidak akan membuat kecewa ataupun sedih. Jadi, konsep 'menjatuhkan' diekspresikan secara ruang yaitu 'dibawah'.

c. Metafora Ontologikal 
Dalam 12 (dua belas) judul lagu yang terdapat pada album Hatsukoi karya Hikaru Utada, peneliti menemukan sebanyak 14 kalimat yang mengandung gaya bahasa metafora ontologikal, yaitu data 2, 3, 6, 17, 30, 31, 32, 34, 37, 39, 40, 41, 43, dan 46 Berikut contoh data yang peneliti temukan dalam lirik lagu pada album Hatsukoi karya Hikaru Utada.

Data [6] アクティヴィストの足音も届かない

Akutivisuto no ashioto mo todokanai

Jejak kaki para aktivis tidak diberitahukan

(あなた 'Anata', 2018)

Pada data [6] ditemukan gaya bahasa metafora ontologikal. Kata 足音 'ashioto'/ jejak kaki merupakan sesuatu yang abstrak namun diperlakukan seperti sesuatu benda konkret. Kata 'jejak kaki' memiliki arti bekas langkah kaki. Namun pada lirik lagu di atas bukan arti tersebut yang dimaksud, melainkan catatan sejarah perjalanan para aktivis. Kata 足音 'ashioto' disini menunjukkan sesuatu yang abstrak namun diekspresikan dalam bahasa sebagai sesuatu yang konkret.

d. Metafora Saluran

Dalam 12 (dua belas) judul lagu yang terdapat pada album Hatsukoi karya Hikaru Utada, peneliti menemukan 2 kalimat yang mengandung gaya bahasa metafora saluran, yaitu data 7 dan 19. Berikut contoh data yang peneliti temukan dalam lirik lagu pada album Hatsukoi karya Hikaru Utada.

Data [7]—終わりのない苦しみを甘受し

Owarai no nai kurushimi wo kanjushi

Terimalah penderitaan yang tidak ada habisnya

(あなた 'Anata', bait ke-11, baris ke-1)

Pada data [7] ditemukan gaya bahasa metafora saluran. Kata 苦しみを甘受 'kurushimi wo kanjushi'/ terimalah penderitaan. Kata 'terimalah' dikonsepkan sebagai suatu proses penyaluran yang dilakukan oleh orang lain terhadap dirinya. Hal yang disalurkan pada lirik lagu tersebut adalah 'penderitaan'. Kata penderitaan yang dimaksud pada lirik lagu di atas adalah keadaan yang sangat menyedihkan yang harus ditanggung. Sesuai dengan konsep metafora saluran bahwa segala sesuatu yang sifatnya menyalurkan suatu hal kepada orang lain, dapat dikelompokkan dalam metafora saluran.

\section{Metonimi}

Metonimi adalah majas perumpamaan yang digunakan untuk menyatakan sesuatu hal (misalnya A) dengan hal lain (misalnya B) atas dasar kedekatan 
(rinsetsu), baik secara ruang (kuukanteki) maupun secara waktu (jikanteki). Adapun hubungan dalam metonimi yaitu a) tempat sesuatu dan isinya (youki-nakami), b) pemilik dan termilik, c) bagian dan keseluruhan (zentai-bubun), d) sebab dan akibat (gen-in-kekka), e) merek dan produknya, e) pencipta dan ciptaannya.

Berdasarkan hasil penelitian, peneliti menemukan sebanyak 12 kalimat yang mengandung gaya bahasa metonimi, dengan rincian: 1 kalimat metonimi yang memiliki hubungan tempat sesuatu dan isinya (youki-nakami), 7 kalimat metonimi yang memiliki hubungan bagian dan keseluruhan (zentai-bubun), dan 4 kalimat metonimi yang memiliki hubungan sebab dan akibat (gen-in---kekka).

a) Tempat sesuatu dan isinya (youki-nakami)

Dalam 12 (dua belas) judul lagu yang terdapat pada album Hatsukoi karya Hikaru Utada, peneliti menemukan 1 kalimat yang mengandung gaya bahasa metonimi yang memiliki hubungan tempat sesuatu dan isinya (youki-nakami), yaitu data 25. Berikut contoh data yang peneliti temukan dalam lirik lagu pada album Hatsukoi karya Hikaru Utada.

Data [25]

$$
\begin{aligned}
& \frac{\text { 溢れる大通りを避けて }}{\text { Afureru oodoori wo sakete }} \\
& \text { Menghindari jalan raya yang meluap }
\end{aligned}
$$

(Forevermore, bait ke-1, baris ke-2)

Pada data [25] ditemukan gaya bahasa metonimi yang memiliki hubungan tempat sesuatu dan isinya (youki-nakami). Kata 溢れる 'afureru’ meluap digunakan untuk kata 大通り 'oodoori'/jalan raya. Namun sebenarnya kata meluap ditujukan untuk orang-orang yang berada di jalan raya. Jadi, yang menjadi bagian adalah sesuatu yang ada di jalan raya, sementara yang menjadi keseluruhan adalah jalan raya.

b) Bagian dan keseluruhan (zentai-bubun)

Dalam 12 (dua belas) judul lagu yang terdapat pada album Hatsukoi karya Hikaru Utada, peneliti menemukan sebanyak 7 kalimat yang mengandung gaya bahasa metonimi yang memiliki hubungan bagian dan keseluruhan (zentai-bubun), yaitu data $10,11,15,16,24,26$, dan 35. Berikut contoh data yang peneliti temukan dalam lirik lagu pada album Hatsukoi karya Hikaru Utada.

Data [16] 優しく肩を打つ雨が今

Yasashiku kata wo utsu ame ga ima

Dan sekarang hujan menerpa bahuku dengan lembut

(初恋 'Hatsukoi', bait ke-12, baris ke-2) 
Pada data [16] ditemukan gaya bahasa metonimi yang memiliki hubungan bagian dan keseluruhan (zentai-bubun). Pada data [16] yang terkena hujan bukan hanya bahunya saja, melainkan seluruh tubuhnya. Dan secara kedekatan antara proses keduanya memiliki kesamaan secara waktu (jikanteki). Pada lirik lagu tersebut juga dapat diartikan bahwa masalah datang secara perlahan dalam kehidupannya.

c) Sebab dan akibat (gen-in---kekka)

Dalam 12 (dua belas) judul lagu yang terdapat pada album Hatsukoi karya Hikaru Utada, peneliti menemukan sebanyak 4 kalimat yang mengandung gaya bahasa metonimi yang memiliki hubungan sebab dan akibat (gen-in---kekka), yaitu data 9, 14, 28, dan 29. Berikut contoh data yang peneliti temukan dalam lirik lagu pada album Hatsukoi karya Hikaru Utada.

Data [9] 静かに頬を伝う涙が

私に知らせるこれが初恋と

Shizuka ni hoho wo tsutau namida ga

Watashi ni shiraseru kore ga hatsukoi to

Air mata mengalir pelan di pipiku

Mereka memberitahuku bahwa ini adalah cinta pertamaku

(初恋 'Hatsukoi', bait ke-1, baris ke-3\&4)

Pada data [9] ditemukan gaya bahasa metonimi yang memiliki hubungan sebab akibat (gen-in---kekka). Kata 涙 'namida'/ air mata merupakan akibat dari proses rasa haru nya karena merasakan cinta pertama. Air mata yang dimaksud adalah tangisan bahagia bukan kesedihan. Sementara penyebab dari air mata (tangisan bahagia) dari tokoh aku adalah ia diberitahu oleh mereka bahwa yang sedang dirasakannya adalah sebuah cinta. Hal ini diperkuat melalui lirik setelahnya yakni 'mereka memberitahuku bahwa ini adalah cinta pertamaku'.

\section{Sinekdoke}

Sinekdoke adalah gaya bahasa yang digunakan untuk menyatakan sesuatu hal (misalnya A) dengan hal lain (misalnya B) atas dasar kekhususan dan keumuman atau hubungan yang bersifat umum dan khusus. Berdasarkan hasil penelitian yang dilakukan pada 12 (dua belas) judul lagu yang terdapat pada album Hatsukoi karya Hikaru Utada, peneliti menemukan sebanyak 7 kalimat yang mengandung gaya bahasa sinekdoke, yaitu data 12, 18, 20, 22, 27, 42, dan 47. Berikut contoh data yang peneliti temukan dalam lirik lagu pada album Hatsukoi karya Hikaru Utada.

Data [18]＼cjkstart綺麗な花も証人もいらない

Kirei na hana mo shounin mo iranai

Saya tidak butuh bunga cantik ataupun saksi 
Pada data [18] ditemukan gaya bahasa sinekdoke. Kata bunga pada lirik lagu tersebut bersifat umum, namun sebenarnya memiliki arti khusus. Bunga yang dimaksud bukanlah bunga kamboja, bunga anggrek, ataupun bunga sakura, melainkan bunga mawar yang sering dijadikan sebagai bunga bouquet pada saat acara pernikahan yang menandakan symbol cinta dan kasih sayang.

\section{Pembahasan}

Dari analisis data penggunaan gaya bahasa yang terdapat pada lirik lagu dalam album Hatsukoi karya Hikaru Utada, peneliti menemukan sebanyak 47 kalimat yang mengandung gaya bahasa. Sebanyak 28 kalimat yang mengandung gaya bahasa metafora dengan pembagian 14 data metafora ontologikal, 10 data metafora konseptual, 2 data metafora orientasional, dan 2 data metafora saluran. Sebanyak 12 kalimat yang mengandung gaya bahasa metonimi dengan pembagian 7 data metonimi yang memiliki hubungan bagian dan keseluruhan (zentai-bubun), 4 data metonimi yang memiliki hubungan sebab dan akibat (gen-in---kekka), dan 1 data metonimi yang memiliki hubungan tempat sesuatu dan isinya (youki-nakami). Dan sebanyak 7 kalimat yang mengandung gaya bahasa sinekdoke.

Jika dikaji ulang dengan penelitian relevan, hasil penelitian ini jauh berbeda dengan penelitian yang dilakukan oleh Setiaji (2018) dengan judul "Analisis Gaya Bahasa yang Terdapat pada Teks Lagu Back Number". Berdasarkan hasil analisis data, gaya bahasa yang paling sering digunakan dalam lirik lagu Back Number yaitu repetisi dengan jumlah 13 data dan simile dengan jumlah 6 data. Karena di dalam lirik lagu Back Number banyak menggunakan pengulangan kata, kosakata yang maknanya bertolak belakang, menggunakan persamaan dengan manusia, penggunaan kata yang tidak sejalan dengan logika, pertanyaan yang makna sesungguhnya adalah pernyataan, kemiripan, penggunaan alat indera, perbandingan, persamaan bunyi, dan gagasan yang bertentangan. Sementara dalam penelitian ini, gaya bahasa yang paling sering digunakan adalah metafora ontologikal dengan jumlah 14 data dan metafora konseptual dengan jumlah 10 data. Karena di dalam lirik lagunya banyak menggunakan kata yang sebenarnya memiliki sifat abstrak namun diekspresikan dengan menggunakan bahasa seperti sesuatu yang konkret. Kemudian, dalam lirik lagu album Hatsukoi banyak menggunakan kalimat yang mengumpamakan akan suatu hal lain, jadi untuk menyatakan hal lain, tidak langsung menggunakan hal tersebut.

\section{KESIMPULAN}

Dari hasil penelitian "Analisis Penggunaan Gaya Bahasa pada Lirik Lagu dalam Album Hatsukoi Karya Hikaru Utada" dengan menggunakan teori Sutedi, maka dapat 
disimpulkan bahwa terdapat 47 lirik lagu yang menggunakan gaya bahasa. Ditemukan sebanyak 28 data yang menggunakan gaya bahasa metafora dengan rincian: 14 data metafora ontologikal, 10 data metafora konseptual, 2 data metafora orientasional, dan 2 data metafora saluran. Kemudian sebanyak 12 data yang menggunakan gaya bahasa metonimi dengan rincian: 7 data metonimi yang memiliki hubungan bagian dan keseluruhan (zentai-bubun), 4 data metonimi yang memiliki hubungan sebab dan akibat (gen-in---kekka), dan 1 data metonimi yang memiliki hubungan tempat sesuatu dan isinya (youki-nakami). Dan yang terakhir, ditemukan 7 data yang menggunaan gaya bahasa sinekdoke. Gaya bahasa yang tidak ditemukan dalam penelitian ini yaitu gaya bahasa metonimi yang memiliki hubungan pemilik dan termilik, merek dan produknya, pencipta dan ciptaannya. Sementara, lagu yang tidak ditemukan adanya penggunaan gaya bahasa di dalamnya yaitu lagu dengan judul パクチーの唄 (Pakuchi No Uta).

Berdasarkan data di atas dapat diketahui bahwa data yang paling banyak ditemukan terdapat pada gaya bahasa metafora ontologikal dengan jumlah 14 data. Kemudian gaya bahasa sinekdoke dengan jumlah 10 data, dan gaya bahasa metonimi yang memiliki hubungan bagian dan keseluruhan (zentai-bubun) dengan jumlah 8 data.

\section{REFERENSI}

Al-Ma'ruf, Ali Imron. 2009. Stilistika: Teori, Metode, dan Aplikasi Pengkajian Estetika Bahasa. Surakarta: Cakra Books.

Ghofur, Muhammad. 2014. "Pemakaian Diksi dan Gaya Bahasa pada Lirik Lagu L'Arc En Ciel'. Skripsi. Surabaya. FIB. UNAIR.

Hermintoyo, M. 2014. Kode Bahasa dan Sastra: Kalimat Metaforis Lirik Lagu Populer. Semarang: Gigih Pustaka Mandiri.

Keraf, Gorys. 2006. Diksi dan Gaya Bahasa. Rev.ed. Jakarta: Gramedia Pustaka Utama.

Moleong, Lexy. 2012. Metodologi Penelitian Kualitatif. Rev.ed. Bandung: Remaja Rosdakarya.

Pradopo, Rachmat. 2014. Pengkajian Puisi. Yogyakarta: Gajahmada University Press.

Ratna, Nyoman. 2009. Stilistika: Kajian Puitika Bahasa, Sastra, dan Budaya.Yogyakarta: Pustaka Pelajar.

Setiaji, Rahmad. 2018. "Analisis Gaya Bahasa yang Terdapat pada Teks Lagu Back Number". Skripsi. Semarang. FBS. UNNES.

Sugiyono. 2013. Metode Penelitian Kombinasi (Mixed Methods). Bandung: Alfabeta.

Sutedi, Dedi. 2004. Dasar-Dasar Linguistik Bahasa Jepang. Rev.ed. Bandung: 
Penggunaan Gaya Bahasa Pada Lirik Lagu - Dharmala Febriyanti ${ }^{1}$, Nova Yulia ${ }^{2}$

Humaniora.

. 2009. Penelitian Pendidikan Bahasa Jepang. Bandung : UPI Press.

2016. Mengenal Linguistik Kognitif. Bandung: Humaniora.

Tarigan, Henry Guntur. 2009. Pengajaran Gaya Bahasa. Rev.ed. Bandung: Angkasa.

Wellek, Renne Dan Austin Warren. 1995. Teori Kesusastraan (Diterjemahkan Oleh Melani Budianta). Jakarta: Gramedia.

Yulia, Nova. 2010. "Bentuk Tsumori dan You To Omou yang Menyatakan Maksud: Kajian Struktur". Jurnal Pendidikan Bahasa, Sastra, dan Seni, Vol. 11(1), 3749.

Zaim,M. 2014. Metode Penelitian Bahasa. Padang: FBS UNP Press.

瀬戸賢一. 2002. 日本語のレトリック: 文章表現の技法.日本. 岩波書店.

小山久美子. 2010 年. “比喻的表現再考”. Journal 川村学園女子大学研究紀要 第 21 巻 第 1 号 1 頁 -10 頁 2010 年. 